\title{
Naturally occurring phytochemical as inhibitors from Catharanthus roseus: An In-silico approaches for drug development against COVID-19
}

\author{
Rishee K. Kalaria ( $\nabla$ risheekal@nau.in ) \\ Navsari Agricultural University https://orcid.org/0000-0002-4481-3834 \\ Hiren K. Patel \\ P. P. Savani University https://orcid.org/0000-0003-0085-2695
}

\section{Research Article}

Keywords: SARS-CoV2, Phytochemicals, Chloroquine, hydroxychloroquine, IMPPAT database, Catharanthus roseus

Posted Date: December 7th, 2020

DOI: https://doi.org/10.21203/rs.3.rs-116443/v1

License: (c) (i) This work is licensed under a Creative Commons Attribution 4.0 International License. Read Full License 


\section{Abstract}

The current outbreak of the novel 2019 Coronavirus disease (COVID-19) is caused by SARS-CoV-2, has developed a threat to the world's human population. There are no effective therapies or vaccines yet, urging the serious efforts to tackle this pandemic situation.SARS-CoV-2 spike protein, papain like protease protein (PLPRO), main protease (3CLpro) and RNA dependent DNA polymerase are key factors in the virus infectious process and have been identified as potential targets for therapeutic formulation. Most people in India depend on conventional Indian medicine (phytochemical compounds) to treat diseases due to lower cost, easier accessibility and no adverse effects. A lot of studies have recently shown that phytochemicals contain an effective anti-viral activity. This study aims to investigate phytochemicals metabolites from the IMPPAT database (Indian Medicinal Plants Database) in order to identify potential COVID-19 inhibitors using in silico approaches. Certain phytochemical compounds with structure analogs like hydroxychloroquine and chloroquine from the IMPPAT database were taken for interaction with SARS-CoV-2 proteins. The Apparicine, 12-Chlorotabersonine, AC1NSULH and Vindolininol identified from Catharanthus roseus were further checked the ADMET property as well as 'Lipinski's rule and resulted in a strong binding affinity of $(-7.6,-7.5)$ and $(-7.6-7.5) \mathrm{kcal} / \mathrm{mol}$ respectively for spikes and papain like protease protein of SARS-CoV-2. Our results indicate that these specific compounds can be used as effective inhibitors and help to pace up the drug development against SARS-CoV-2. Further investigation and testing of these inhibitors against SARS-CoV-2 are however required to check their clinical trial candidacy.

\section{Introduction}

The epic coronavirus disease 2019 (COVID-19), as a result of the extreme acute respiratory syndrome coronavirus-2 (SARS-CoV-2), is within the midst of world panic and global health challenge considering that china, December 2019. As of $12^{\text {th }}$ May 2020, the World Health Organization (WHO) has stated that 40,88,848 and 2,83,153 death cases had been confirmed global, and it has spread to 197 countries [1].

The COVID-19 spread unexpectedly over the globe, turning into a pandemic inside half a month and apart from China, the information of the carnage started out pouring in from nations like the USA, Italy, Spain, France, Germany and Iran along with India on an everyday basis. After the first case of the COVID-19 on 30 ${ }^{\text {th }}$ January 2020 in India, there turn out to be 83,004 cases and 4,337 deaths as in keeping with legitimate information of the ministry of health and family welfare, India on $27^{\text {th }}$ May,2020 [1].

Tragically, there has been no perceptible achievement in the administration of this ailment to date and the patient is given a treatment dependent on his recognizable and diagnosable manifestations. Albeit a few endeavours have been made in the research and development of the diagnostics, therapeutics and vaccines for this novel coronavirus[2], there occurs no chemotherapeutic agent up to now which has been shown unequivocally to be compelling in treating human illnesses because of a minute virus. To combat this lethal COVID-19, a number of ordinary drugs [3],[4] like chloroquine, hydroxychloroquine, remdesivir, and so forth, have been tried and located with positive healing effect in vitro. However, the clinical drug response isn't very promising and harmfulness stays an unavoidable issue causing genuine antagonistic effects [5]

Coronaviruses possess the largest genomes (26.4-31.7 kb) among all known RNA viruses, with $\mathrm{G}+\mathrm{C}$ contents varying from 32 to 43 percent. Variable numbers of small ORFs are present between the various conserved genes (ORF1ab, spike, envelope, membrane and nucleocapsid) and, downstream to the nucleocapsid gene in different coronavirus lineages [6]. Two-thirds of viral RNA, mainly located in the first ORF (ORF1a/b) translates two polyproteins, pp1a and pp1ab, and encodes 16 non-structural proteins (NSP), while the remaining ORFs encode accessory and structural proteins. The rest part of virus genome encodes four essential structural proteins, including spike (S) glycoprotein, small envelope (E) 
protein, matrix (M) protein, and nucleocapsid (N) protein [7], and also several accessory proteins, that interfere with the host innate immune response. In SARS coronavirus, a defined receptor-binding domain (RBD) on S protein mediates attachment of the virus to its cellular receptor, angiotensin-converting enzyme 2 (ACE2). The most abundant and conserved N protein of SARS-CoV-2 is 90 percent identical to SARS-CoV N protein. Moreover, the SARS-CoV-2 genome showed 80 percent identity with SARS-CoV and 89 percent similarity with Bat SARS-like CoV at nucleotide level [8]. Most SARS-CoV-2 genomic encoded proteins are similar to SARS-CoVs, though some deviations however exist. In order to be able to understand the best phytochemical that could bind to most conserved protein spike ectodomain protein [9], papain-like protease protein, main protease protein [10] and RNA-dependent RNA polymerase and help stop the spread of the virus, many researchers have begun to use molecular docking techniques to identify phytochemical that can be used to inhibit.

Because of the inherent aspect outcomes of the synthetic chemical compounds used in allopathic tablets, a sizeable populace has exchanged over to the traditional system of medicine (natural medication) for his or her number one fitness care. Ayurveda, the age-old Indian system of medicine, is an increasing number of becoming a well-known system to financial institution on. The ayurvedic treatment has become an alternative to conventional medicines due to several reasons including easy availability, less or no side effects and less cost. India has consistently been a rich supply of therapeutic plants in view of a few agro-climatic zones [11]. The act of utilizing therapeutic plants to treat human skin including mending of wounds and consume wounds, antifungal, antiviral, antibacterial applications against skin contaminations has long history and is continuing for essential medicinal healthcare even in the cutting edge [12]-[13]. ZINC is a public database of available commercially for virtual-screening compounds. It contain a library of 727842 molecules, each with 3D structure, using catalogs of compounds from vendors. Significant biological protonation states have been attributed to the molecules and they are annotated with characteristics such as molecular weight, calculated LogP and number of rotatable bonds etc. Each molecule in the library contains vendor and purchasing information and is ready for docking using a number of popular docking programs [14]. IMPPAT is a curated database stands for Indian Medicinal Plants, Phytochemistry and Therapeutics. It is a comprehensive online database on the phytochemistry of Indian medicinal plants will enable computational approaches towards natural product based drug discovery. In this direction, IMPPAT has a manually curated database of 1742 Indian Medicinal Plants, 9596 Phytochemicals, and 1124 therapeutic uses spanning 27074 plant-phytochemical associations and 11514 plant-therapeutic associations. In particular, the cure effort resulted in a non-redundant 9596 phytochemicals in silico library with standard chemical identities and structure properties. Using cheminformatic approaches, scientist has computed the physicochemical, ADMET (absorption, distribution, metabolism, excretion, toxicity) and drug-likeliness properties of the IMPPAT phytochemicals. It also show that the stereochemical complexity and shape complexity of IMPPAT phytochemicals differ from libraries of commercial compounds or diversity-oriented synthesis compounds while being similar to other libraries of natural products [15].

Catharanthus roseus is a one of evergreen consistently sprouting herb which has its inception in focal Madagascar island. Periwinkle is recorded for as back as 50 B.C. in people medication writing of Europe as diuretic, hemorrhagic and wound recuperating. Because of high therapeutic value of many phytochemical residences, globally scientist and researchers perceive dozens of alkaloids: some of them lower blood sugar levels (supplying folk treatments with medical provenance) and blood pressure [16]. The point of present investigation is to check the antiviral capability of $C$. roseus fixings against COVID-19 by methods for computational strategies. The middle intent of this study is to inhibit or weaken the interactions between the receptor and RBD by using phytocompounds that could block or abate viral entry into the host cells [16].

Hence, this work is aimed to identify potential plant-based compounds that can serve as substitutes and can help us in blocking the 'SARS-CoV2 'protein function. In the near future, upon further laboratory experiment these phytochemicals that serve as good contestants for the treatment of diseases caused by eliminating SARSCoV2-associated pathogenesis. 


\section{Materials And Methods}

\subsection{Retrieving of target proteins as receptors:}

The three-dimensional crystal structures were considered as potential targets of all recently reported SARS-CoV2 proteins. Spike ectodomain protein (open state) (PDB ID: 6VYB) [9], papain-like protease protein (PDB ID: 6W9C), main protease protein (PDB ID: 6YB7) [10] and RNA-dependent RNA polymerase (PDB ID: 7BTF) [17] [18] were collected from the PDB database [19].

\subsection{Retrieving of Natural phytochemicals as Ligands:}

The smiles format of recently used drugs as ligands (Hydroxychloroquine and chloroquine) [17];[20] were downloaded from the PubChem database and then potential analog were identified in IMPPAT database which include all the photochemical compounds from Indian medicinal plants [15] (Fig. 2) (Table 1).

Table 1: List of Potential Phytochemicals as ligands from IMPPAT database 


\begin{tabular}{|c|c|c|c|c|}
\hline $\begin{array}{l}\text { Sr. } \\
\text { No. }\end{array}$ & $\begin{array}{l}\text { Drugs with Canonical } \\
\text { smiles format }\end{array}$ & $\begin{array}{l}\text { Analogs Photochemical } \\
\text { with Canonical smiles format }\end{array}$ & $\begin{array}{l}\text { Photochemical } \\
\text { class }\end{array}$ & Source \\
\hline \multirow[t]{12}{*}{1} & Hydroxychloroquine & 1) (-)-Apparicine & $\begin{array}{l}\text { Vallesaman } \\
\text { alkaloids }\end{array}$ & $\begin{array}{l}\text { Catharanthus } \\
\text { roseus }\end{array}$ \\
\hline & PubChem CID: 3652 & CID_5281349(IMPPAT ID) & & \\
\hline & $\operatorname{CCN}(\operatorname{CCCC}(\mathrm{C}) \mathrm{NC} 1=\mathrm{C} 2 \mathrm{C}=$ & $\mathrm{C} / \mathrm{C}=\mathrm{C} 1 / \mathrm{CN} 2 \mathrm{CC}[\mathrm{C} @ @ \mathrm{H}] 1 \mathrm{C}(=\mathrm{C})$ & & \\
\hline & $\mathrm{CC}(=\mathrm{CC} 2=\mathrm{NC}=\mathrm{C} 1) \mathrm{Cl}) \mathrm{CCO}$ & $\mathrm{c} 1 \mathrm{c}(\mathrm{C} 2) \mathrm{c} 2 \mathrm{c}([\mathrm{nH}] 1) \mathrm{cccc} 2$ & & \\
\hline & & 2) Apparicine (Gomezine) & $\begin{array}{l}\text { Vallesaman } \\
\text { alkaloids }\end{array}$ & $\begin{array}{l}\text { Catharanthus } \\
\text { roseus }\end{array}$ \\
\hline & & CID_5320486 (IMPPAT ID) & & \\
\hline & & $\mathrm{C} / \mathrm{C}=\mathrm{C} / 1 \mathrm{CN} 2 \mathrm{CCC} 1 \mathrm{C}(=\mathrm{C}) \mathrm{c} 1 \mathrm{C}$ & & \\
\hline & & $(\mathrm{C} 2) \mathrm{c} 2 \mathrm{c}([\mathrm{nH}] 1) \mathrm{cccc} 2$ & & \\
\hline & & 3) 12-Chlorotabersonine & $\begin{array}{l}\text { Plumeran-type } \\
\text { alkaloids }\end{array}$ & $\begin{array}{l}\text { Catharanthus } \\
\text { roseus }\end{array}$ \\
\hline & & CID_25109982 (IMPPAT ID) & & \\
\hline & & COC $(=0) C 1=C 2 N c 3 c([C @ @] 42[C @ @$ & & \\
\hline & & $\mathrm{H}] 2[\mathrm{C} @ @](\mathrm{C} 1)(\mathrm{CC}) \mathrm{C}=\mathrm{CCN} 2 \mathrm{CC} 4) \mathrm{cc}(\mathrm{cc} 3) \mathrm{Cl}$ & & \\
\hline \multirow[t]{12}{*}{2} & Chloroquine & 4) AC1NSULH ((16R)-Dihydrositsirikine & Corynanthean- & Catharanthus \\
\hline & & $6519-26-2)$ & & \\
\hline & PubChem CID: 2719 & & & \\
\hline & $\operatorname{CCN}(\operatorname{CCCC}(\mathrm{C}) \mathrm{NC} 1=\mathrm{C} 2 \mathrm{C}=$ & CID_5316739 (IMPPAT ID) & & \\
\hline & $\mathrm{CC}(=\mathrm{CC} 2=\mathrm{NC}=\mathrm{C} 1) \mathrm{Cl}) \mathrm{CCO}$ & & & \\
\hline & & $\operatorname{cCC} 1 \mathrm{CN} 2 \mathrm{CC} 3 \mathrm{c}(\mathrm{C} 2 \mathrm{CC} 1 \mathrm{C}(\mathrm{C}(=0) \mathrm{OC})$ & & \\
\hline & & $\mathrm{CO})[\mathrm{nH}] \mathrm{c} 1 \mathrm{c} 3 \mathrm{cccc} 1$ & & \\
\hline & & 5) Vindolininol & $\begin{array}{l}\text { Indoles and } \\
\text { derivatives }\end{array}$ & $\begin{array}{l}\text { Catharanthus } \\
\text { roseus }\end{array}$ \\
\hline & & CID_101287751 (IMPPAT ID) & & \\
\hline & & OC[C@@H]1C[C@]23[C@H]([C@]41Nc & & \\
\hline & & 1c([C@@]54[C@H]3N(CC5)CC=C2)cccc1)C & & \\
\hline & & 6) Velbanamine & $\begin{array}{l}\text { Indoles and } \\
\text { derivatives }\end{array}$ & $\begin{array}{l}\text { Catharanthus } \\
\text { roseus }\end{array}$ \\
\hline
\end{tabular}


CID_102399433 (IMPPAT ID)

CC[C@@]1(0)C[C@@H]2CCc3c(CCN

$(\mathrm{C} 1) \mathrm{C} 2) \mathrm{c} 1 \mathrm{c}([\mathrm{nH}] 3) \mathrm{cccc} 1$

\subsection{Screening of compounds:}

\subsubsection{Evaluation of Lipinski parameters for drug-likeness:}

A drug likeliness property of all potential phytochemical compounds were assessed using the molinspiration server [21].

\subsubsection{ADMET analysis:}

The SwissADME and PROTOX-II webservers were provided with all potential phytochemical compounds as ligands in smiles format for ADMET analysis. The SwissADME is a tool used to forecast compound ADME and pharmacokinetic properties, toxicity, water solubility, and molar refractivity [22]. PROTOX-II is an oral toxicity rodent server that forecasts the value of LD50 and the level of toxicity of a request compounds in six distinct classes varying from LD5 to 5000 with its implications [23].

\subsection{In silico docking of phytochemicals with targets Protein of SARS-CoV2:}

The active site pocket present in the spike ectodomain protein, papain-like protease protein, main protease protein and RNA-dependent RNA polymerase of SARS-CoV2 were analysed using the CASTp server [24]. Active pocket with the maximum volume as well as surface area were considered for molecular docking studies with all phytochemicals [25] through the AutoDock [26] tool. For further analysis, each potentials phytochemical with the minimum binding energy was considered with proteins of SARS-CoV2 [25]. The results were analyzed using MGL tool 1.5.6 to evaluate the residues of amino acids associated with drug binding [26] and the hydrophilic and hydrophobic interactions were measured using PyMol [27] in docking with the maximum binding energies of Ligands receptors.

\section{Results}

\subsection{Preparation of SARS-CoV2 protein as receptor:}

All recently deposited protein structure of SARS-CoV2 protein including spike ectodomain protein (open state) (PDB ID: 6VYB), papain-like protease protein (PDB ID: 6W9C), main protease protein (PDB ID: 6YB7) and RNA-dependent RNA polymerase (PDB ID: 7BTF) retrieved from PDB database in native form after eliminating ligands, carbohydrates etc components attached to it (Fig.1a and Fig.1b). To remove water molecules and add polar hydrogen charges in MGL tool 1.5.6, all PDB structures were further processed.

CASTp server analyzed all the target protein structures for identified amino acid residues present in the active site pocket. Spike ectodomain protein showed smaller surface area versus volume binding pocket with amino acid residues ranges from 24-THR to 192-GLN while papain-like protease protein, main protease protein and RNA-dependent RNA polymerase showed larger surface area versus volume binding pocket with amino acid residues ranges from 9-THR to 302-ASP, 90MET to 164-ASP, 38-TYR to 1064-HIS respectively (Fig.3a and Fig.3b; Table 2). 


\begin{tabular}{|llll|}
\hline $\begin{array}{l}\text { Sr. } \\
\text { No. }\end{array}$ & Protein & $\begin{array}{l}\text { Most probable binding } \\
\text { pocket }\end{array}$ & $\begin{array}{l}\text { Amino acid residues in the binding } \\
\text { pocket }\end{array}$ \\
\hline 1 & spike ectodomain protein & 299.292 surface area & 24-THR to 192GLN \\
& & 299.903 surface volume & \\
\hline 2 & papain-like protease protein & 8882.658 surface area & 9-THR to 302 ASP \\
& & 15688.230 surface volume & \\
\hline 3 & main protease protein & 3197.242 surface area & 90-MET to 164 ASP \\
\hline 4 & $\begin{array}{l}\text { RNA-dependent RNA } \\
\text { polymerase }\end{array}$ & 3692.411 surface volume & \\
\hline
\end{tabular}

\subsection{Preparation of Phytochemicals compounds as ligands:}

Potential drugs hydroxychloroquine (PubChem CID3652) and chloroquine in (PubChem CID:2719) smiles format or canonical smiles format from the PubChem database were further compared with the IMPPAT database to find drugs analog as natural compounds or phytochemicals available from Indian medicinal plants having therapeutic values.

Only a few phytochemical compounds were recovered, based on the Tanimoto coefficient. For drugs hydroxychloroquine analog compounds as (-)-Apparicine (CID_5281349), Apparicine (Gomezine) (CID_5320486) and 12-Chlorotabersonine (CID_25109982) while chloroquine drug analog compounds as AC1NSULH ((16R)-Dihydrositsirikine 6519-26-2) (CID_5316739), Vindolininol (CID_101287751) and Velbanamine CID_102399433 were further taken for consideration(Table 1). Majority all the phytochemicals compounds belongs to Catharanthus roseus having wide ranges of alkaloids used for therapeutics.

All possible phytochemical compounds qualified all the filters in the molinspiration server for Lipinski parameters for drug-likeness. AC1NSULH ligand showed the maximum TPSA-65.56,nON-5, volume-341.35 and miLog p-4.34 of 12Chlorotabersonine with nOHNH-2 each for AC1NSULH, Vindolininol and Velbanamine(Table 3). In ADMET analysis, maximum Consensus Log Po/w of 12-Chlorotabersonine with moderate water solubility and TPSA of AC1NSULH with 65.56 Å2. All phytochemicals had high GI absorption, behave as drug likeness and 0 Violation of Lipinski's rule of five, making them excellent potential candidates as COVID-19 drugs (Table 4). All drug toxicity phytochemicals revealed common similarity with levels-4 and LD50 as $1190 \mathrm{mg} / \mathrm{kg}$ with a high similarity ratio (Table 5). From the study of ADMET and PROTOX-II, all potential candidate ligands passed these test filters overall.

\section{Table 3: Lipinski rule passed by phytochemical compounds consider as ligands}




\begin{tabular}{|llllllll|}
\hline Ligands & $\begin{array}{l}\text { miLog } \mathbf{p} \\
\text { (Molinspiration } \\
\text { logP value) }\end{array}$ & $\begin{array}{l}\text { TPSA } \\
\text { (polar } \\
\text { surface } \\
\text { area) }\end{array}$ & $\begin{array}{l}\text { MW } \\
\text { molecular } \\
\text { weight }\end{array}$ & $\begin{array}{l}\text { nON } \\
\text { H-bond } \\
\text { acceptors }\end{array}$ & $\begin{array}{l}\text { nOHNH } \\
\text { H-bond } \\
\text { donors }\end{array}$ & $\begin{array}{l}\text { RB: Number of } \\
\text { rotatable } \\
\text { bonds }\end{array}$ & Volume \\
\hline ()-Apparicine & 3.68 & 19.03 & 264.37 & 2 & 1 & 1 & 259.87 \\
\hline AC1NSULH & 3.71 & 65.56 & 356.47 & 5 & 2 & 3 & 341.35 \\
\hline Apparicine & 3.68 & 19.03 & 264.37 & 2 & 1 & 1 & 259.87 \\
\hline $\begin{array}{l}\text { 12- } \\
\text { Chlorotabersonine }\end{array}$ & 4.34 & 41.57 & 370.88 & 4 & 1 & 3 & 329.17 \\
\hline Vindolininol & 2.79 & 35.49 & 308.43 & 3 & 2 & 1 & 291.02 \\
\hline Velbanamine & 3.65 & 39.26 & 298.43 & 3 & 2 & 1 & 296.45 \\
\hline
\end{tabular}

Table 4: ADME properties of Phytochemical compounds predicted by SwissADME

\begin{tabular}{|c|c|c|c|c|c|c|c|}
\hline \multirow[t]{2}{*}{ Ligands } & \multicolumn{7}{|l|}{ SwissADME } \\
\hline & $\begin{array}{l}\text { Consensus } \\
\text { Log Po/w }\end{array}$ & $\begin{array}{l}\text { Water } \\
\text { solubility }\end{array}$ & $\begin{array}{l}\text { GI } \\
\text { absorption }\end{array}$ & $\begin{array}{l}\text { Drug- } \\
\text { likeness }\end{array}$ & $\begin{array}{l}\text { TPSA } \\
\text { (topological } \\
\text { polar } \\
\text { surface } \\
\text { area)(Å2) }\end{array}$ & $\begin{array}{l}\text { Lipinski's } \\
\text { rule of } \\
\text { five }\end{array}$ & Pain \\
\hline (-)-Apparicine & 3.29 & soluble & High & Yes & 19.03 & $\begin{array}{l}0 \\
\text { Violation }\end{array}$ & 0 Alert \\
\hline AC1NSULH & 2.64 & soluble & High & Yes & 65.56 & $\begin{array}{l}0 \\
\text { Violation }\end{array}$ & $\begin{array}{l}1 \text { alert: } \\
\text { indol_3yl_alk }\end{array}$ \\
\hline Apparicine & 3.30 & soluble & High & Yes & 19.03 & $\begin{array}{l}0 \\
\text { Violation }\end{array}$ & 0 alert \\
\hline $\begin{array}{l}12- \\
\text { Chlorotabersonine }\end{array}$ & 3.51 & $\begin{array}{l}\text { Moderately } \\
\text { soluble }\end{array}$ & High & Yes & 41.57 & $\begin{array}{l}0 \\
\text { Violation }\end{array}$ & 0 alert \\
\hline Vindolininol & 2.40 & soluble & High & Yes & 35.50 & $\begin{array}{l}0 \\
\text { Violation }\end{array}$ & 0 alert \\
\hline Velbanamine & 3.06 & soluble & High & Yes & 39.26 & $\begin{array}{l}0 \\
\text { Violation }\end{array}$ & $\begin{array}{l}1 \text { alert: } \\
\text { indol_3yl_alk }\end{array}$ \\
\hline
\end{tabular}

Table 5: Toxicity prediction of hydroxychloroquine predicted by PROTOX-II 


\begin{tabular}{|c|c|c|c|c|}
\hline \multicolumn{5}{|c|}{ PROTOX-II } \\
\hline Ligands & Class & $\begin{array}{l}\text { LD50 } \\
(\mathrm{mg} / \mathrm{kg})\end{array}$ & Average similarity & Prediction accuracy \\
\hline (-)-Apparicine & 4 & 1190 & $100 \%$ & $100 \%$ \\
\hline AC1NSULH & 4 & 1190 & $100 \%$ & $100 \%$ \\
\hline Apparicine & 4 & 1190 & $100 \%$ & $100 \%$ \\
\hline 12-Chlorotabersonine & 4 & 1190 & $100 \%$ & $100 \%$ \\
\hline Vindolininol & 4 & 1190 & $100 \%$ & $100 \%$ \\
\hline Velbanamine & 4 & 1190 & $100 \%$ & $100 \%$ \\
\hline
\end{tabular}

\subsection{In silico docking of phytochemicals with targets Protein of SARS-CoV2:}

Considering active site pocket of SARS-CoV2 Protein (spike ectodomain protein, papain-like protease protein, main protease protein and RNA-dependent RNA polymerase ) as receptor were further interacted with ligands as phytochemicals compounds ((-)-Apparicine, Apparicine, 12-Chlorotabersonine AC1NSULH, Vindolininol and Velbanamine) using AutoDock tool to identified minimum binding energy and MGL tool 1.5.6 to identify the amino acid residues involved in drug binding. These ligands were classified by their binding energy (provided by virtual screening based on AutoDock VINA in blind docking mode, approx. 960 conformations). In molecular docking, spike ectodomain protein with ligands apparicine and 12-Chlorotabersonine having -7.6 and $-7.5 \mathrm{kcal} / \mathrm{mol}$ respectively minimal binding energy and maximum hydrogen bond involved with interacted amino acid (LEU763,GLN 1002, GLN1005,THR 1006,THR1009 and GLN1010) and (LEU763,GLN1002, GLN1005, THR 1006,THR1009,GLN1010) respectively (Fig.4a and Fig.5a)(Table 6).

Table 6: Docking calculations depicting interacting residues and Binding affinity of target proteins with Ligand 


\begin{tabular}{|c|c|c|c|c|}
\hline $\begin{array}{l}\text { Sr. } \\
\text { No. }\end{array}$ & Protein Name & Ligand & Interacted residues & $\begin{array}{l}\text { Binding } \\
\text { affinity } \\
\text { (kcal/mol) }\end{array}$ \\
\hline \multirow[t]{4}{*}{1} & \multirow{4}{*}{$\begin{array}{l}\text { spike } \\
\text { ectodomain } \\
\text { protein }\end{array}$} & \multirow[t]{2}{*}{ 1) Apparicine } & $\begin{array}{l}\text { LEU763,GLN 1002, GLN1005,THR 1006,THR1009 and } \\
\text { GLN1010 }\end{array}$ & \multirow[t]{2}{*}{-7.6} \\
\hline & & & (6 H bond presents) & \\
\hline & & \multirow[t]{2}{*}{$\begin{array}{l}\text { 2)12- } \\
\text { Chlorotabersonine }\end{array}$} & $\begin{array}{l}\text { LEU763,GLN1002, GLN1005, THR } \\
\text { 1006,THR1009,GLN1010 }\end{array}$ & \multirow[t]{2}{*}{-7.5} \\
\hline & & & (7 H bond presents) & \\
\hline \multirow[t]{4}{*}{2} & \multirow[t]{4}{*}{$\begin{array}{l}\text { papain-like } \\
\text { protease protein }\end{array}$} & \multirow[t]{2}{*}{ 1) AC1NSULH } & $\begin{array}{l}\text { ASN109, THR 158, VAL159, GLY160, GLU161 and } \\
\text { LEU162, GLN269 }\end{array}$ & \multirow[t]{2}{*}{-7.6} \\
\hline & & & (5 $\mathrm{H}$ bond presents) & \\
\hline & & \multirow[t]{2}{*}{ 2) Vindolininol } & $\begin{array}{l}\text { ASP108,ASN109,VAL159, GLY160, GLU161 and } \\
\text { LEU162 }\end{array}$ & \multirow[t]{2}{*}{-7.5} \\
\hline & & & (5 H bond presents) & \\
\hline \multirow[t]{2}{*}{3} & \multirow[t]{2}{*}{$\begin{array}{l}\text { main protease } \\
\text { protein }\end{array}$} & \multirow[t]{2}{*}{ Vindolininol } & $\begin{array}{l}\text { LYS5,TYR126, GLN127, CYS128,LYS137, GLU288 } \\
\text { and GLU290 }\end{array}$ & \multirow[t]{2}{*}{-3.4} \\
\hline & & & (3 H bond presents) & \\
\hline \multirow[t]{2}{*}{4} & \multirow[t]{2}{*}{$\begin{array}{l}\text { RNA-dependent } \\
\text { RNA } \\
\text { polymerase }\end{array}$} & \multirow[t]{2}{*}{ AC1NSULH } & $\begin{array}{l}\text { ARG553,ARG555,ASP618, TYR619, } \\
\text { CYS622,ASP623,THR680, SER681,SER682, } \\
\text { THR687,ASN691 and ASP760 }\end{array}$ & \multirow[t]{2}{*}{-6.3} \\
\hline & & & (5 H bond presents) & \\
\hline
\end{tabular}

Papain-like protease protein with ligands AC1NSULH and Vindolininol having -7.6 and $-7.5 \mathrm{kcal} / \mathrm{mol}$ respectively minimal binding energy and maximum hydrogen bond involved with interacted amino acid (ASN109, THR 158, VAL159, GLY160, GLU161 and LEU162, GLN269) and (ASP108,ASN109,VAL159, GLY160, GLU161 and LEU162) (Fig.4a and Fig.5b) respectively.

Main protease protein with ligands Vindolininol and RNA-dependent RNA polymerase with ligands AC1NSULH having -3.4 and $-6.3 \mathrm{kcal} / \mathrm{mol}$ respectively minimal binding energy and maximum hydrogen bond involved with interacted amino acid (LYS5, TYR126, GLN127, CYS128, LYS137, GLU288 and GLU290) and (ARG553, ARG555, ASP618, TYR619, CYS622, ASP623, THR680, SER681, SER682, THR687 ,ASN691 and ASP760) respectively (Fig.4b, and Fig.5c). Those phytochemical compounds that reliably qualified with AutoDock VINA binding energy thresholds of $<-7 \mathrm{kcal} / \mathrm{mol}$ may be considered more suitable for further examinations than the other compounds.

\section{Discussion}

Even the rate of COVID-19 infection in shocking outbreaks worldwide is increasing day by day with a big risk of a pandemic situation. Within such circumstances in the near future, if it will not available then it will be difficult to manage the outbreak without drugs and vaccines. There is an immediate need for a multinational and remarkable effort to quickly identify an effective drug for SARSCoV2 [28]- [29]. For our computational approach we have identified four essential viral proteins, i.e. spike protein, papain-like protease protein, main protease protein and RNA-dependent RNA polymerase. Spike protein assists in initial host cell communication with the virus [30]. An important catalytic domain, essential for viral 
replication, is RNA-dependent polymerase, papain-like protease protein (PLpro) and main protease protein (3CLpro). All are prime focus for the development of coronavirus drugs and vaccines [31]- [32].

In the field of computer-aided drugs designed especially to recognise a probable compound as ligands in molecular docking is extensively used to explore the different types of binding interaction between the prospective drug and the distinct domains or active sites on the target proteins and the nature of the residues presented at the active site. The information on binding energy ( $\mathrm{Kcal} / \mathrm{mol}$ ) facilitates us to study and compare the binding affinity of various ligands with their corresponding target receptor molecule. The most affinated ligand can be assigned as the potential drug for further studies [33].

Rane et al [33] investigated ten pytochemicals analogous to hydroxychloroquine drugs for interaction with SARSCoV2 spike protein. Quercetin and fisetin showed lowest and identical binding energy of -8,5 kcal / mol binding perceptions for spike protein compared with $-5,6 \mathrm{kcal} /$ mol hydroxychloroquine. The fisetin interacts with residues of SER 730, THR 778 and HIS 1058 by $\mathrm{H}$-bonding and induces hydrophobic interaction S2 of the spike protein domain residues of ILE 870, PRO 880 and THR 732. Whereas quercetin forms residues of hydrogen with LYS 733, LEU 861, MET 731,SER730,PRO 1057, GLY 1059, HIS 1058 and ALA 1056 and indicates hydrophobic interactions with ILE 870, ASP 867, MET 730, VAL 860 and PRO 863.

Kadioglu et al [29] studied 39,442 phytochemicals compounds from ZINC database analog to 1,577 FDA approved drugs for interaction with spike, 2'-o-ribosemethyltransferase and nucleocapsid protein of SARSCoV2. phytochemical compounds amyrin, ZINC000027215482 and ZINC000252515584 bound to spike protein with $-7.42 \mathrm{Kcal} / \mathrm{mol}$ and nucleocapsid with $-8.80 \mathrm{Kcal} / \mathrm{mol}$ while procyanidin bound to spike protein with $-7.29 \mathrm{Kcal} / \mathrm{mol}, 2^{\prime}-0$ ribosemethyltransferase with $-10.64 \mathrm{Kcal} / \mathrm{mol}$ and nucleocapsid with $-5.16 \mathrm{Kcal} / \mathrm{mol}$. It is documented that phytochemical compounds bind on more than one target [31]. In this regard, we expect that our approach through phytochemical drugs that obstacle against major novel coronavirus (COVID-19) target proteins can be of great assistance in such a globally initiative.

\section{Conclusions}

The framework to modifying drugs would be the quickest and most effective decision to find therapeutic remedies for the Coronavirus Novel SARSCoV2 (COVID-19). The methodology to bioinformatics may be a very useful strategy in identifying potential inhibitors against the SARS-CoV-2. In this research, the evaluation of possible natural phytochemical drugs mainly secondary metabolites from the IMPPAT database as apparicine, 12-Chlorotabersonine, AC1NSULH, and Vindolininol identified from Catharanthus roseus resulted in a great binding affinity with the spike and papain-like protease-protein. Such phytochemical drugs often resulted in more than one binding to target proteins and at the same time raising the diagnostic accuracy and reducing the likelihood of resistance development to one of the targets which provide justification for therapeutic development to combat COVID-19. To the best of our knowledge, we are the first to identify candidates as phytochemicals from Indian medicinal plants against SARS-CoV-2 viral proteins in the silico approach. In the near future further experiments in vitro and in vivo with our potential phytochemical compounds will find a way to treat SARS-CoV-2 infections.

\section{Declarations}

\section{Compliance with ethical standards}

Conflict of Interest: The authors declare no potential conflicts of interest.

Ethical approval: This research did not involve any experimentation on humans or animals.

Page $11 / 16$ 


\section{Author information:}

Rishee K. Kalaria and Hiren Patel contributed equally to this work.

\section{References}

1. Organization WH. Laboratory testing of 2019 novel coronavirus ( 2019-nCoV) in suspected human cases: interim guidance, 17 January 2020. 2020.

2. Li G, De Clercq E. Therapeutic options for the 2019 novel coronavirus (2019-nCoV). Nature Publishing Group; 2020.

3. Wang M, Cao R, Zhang L, Yang X, Liu J, Xu M et al. Remdesivir and chloroquine effectively inhibit the recently emerged novel coronavirus (2019-nCoV) in vitro. Cell research. 2020;30(3):269-71.

4. Liu J, Cao R, Xu M, Wang X, Zhang H, Hu H et al. Hydroxychloroquine, a less toxic derivative of chloroquine, is effective in inhibiting SARS-CoV-2 infection in vitro. Cell discovery. 2020;6(1):1-4.

5. Sheahan TP, Sims AC, Leist SR, Schäfer A, Won J, Brown AJ et al. Comparative therapeutic efficacy of remdesivir and combination lopinavir, ritonavir, and interferon beta against MERS-CoV. Nature Communications. 2020;11(1):1-14.

6. Woo PC, Huang Y, Lau SK, Yuen K-Y. Coronavirus genomics and bioinformatics analysis. viruses. 2010;2(8):1804-20.

7. Cui J, Li F, Shi Z-L. Origin and evolution of pathogenic coronaviruses. Nature reviews Microbiology. 2019;17(3):18192.

8. Gralinski L, Menachery V. Return of the Coronavirus: 2019-nCoV. Viruses. 2020; 12: 135. Google Scholar.

9. Lan J, Ge J, Yu J, Shan S, Zhou H, Fan S et al. Structure of the SARS-CoV-2 spike receptor-binding domain bound to the ACE2 receptor. Nature. 2020:1-6.

10. Mesecar A. A taxonomically-driven approach to development of potent, broad-spectrum inhibitors of coronavirus main protease including SARS-CoV-2 (COVID-19). Be Publ. 2020.

11. Srivastava AK, Kumar A, Misra N. On the Inhibition of COVID-19 Protease by Indian Herbal Plants: An In Silico Investigation. arXiv preprint arXiv:200403411. 2020.

12. Shahid MA, Ali A, Uddin MN, Miah S, Islam SM, Mohebbullah M et al. Antibacterial wound dressing electrospun nanofibrous material from polyvinyl alcohol, honey and Curcumin longa extract. Journal of Industrial Textiles. 2020:1528083720904379.

13. Ali A, Shahid MA, Hossain MD, Islam MN. Antibacterial bi-layered polyvinyl alcohol (PVA)-chitosan blend nanofibrous mat loaded with Azadirachta indica (neem) extract. International journal of biological macromolecules. 2019;138:1320.

14. Irwin JJ, Shoichet BK. ZINC- a free database of commercially available compounds for virtual screening. Journal of chemical information and modeling. 2005;45(1):177-82.

15. Mohanraj K, Karthikeyan BS, Vivek-Ananth R, Chand RB, Aparna S, Mangalapandi P et al. IMPPAT: A curated database of Indian medicinal plants, phytochemistry and therapeutics. bioRxiv. 2017:206995.

16. Kaushik S, Singh R, Monika T, Raghvendra G, Mishra K. An overview of Catharanthus roseus and medicinal properties of their metabolites against important diseases. Eur Acad Res. 2017;2:1237-47.

17. Gao J, Tian Z, Yang X. Breakthrough: Chloroquine phosphate has shown apparent efficacy in treatment of COVID-19 associated pneumonia in clinical studies. Bioscience trends. 2020.

18. Walls AC, Park Y-J, Tortorici MA, Wall A, McGuire AT, Veesler D. Structure, function, and antigenicity of the SARS-CoV2 spike glycoprotein. Cell. 2020.

19. Bernstein FC, Koetzle TF, Williams GJ, Meyer Jr EF, Brice MD, Rodgers JR et al. The Protein Data Bank: a computerbased archival file for macromolecular structures. Archives of biochemistry and biophysics. 1978;185(2):584-91.

Page $12 / 16$ 
20. Singh AK, Singh A, Shaikh A, Singh R, Misra A. Chloroquine and hydroxychloroquine in the treatment of COVID-19 with or without diabetes: A systematic search and a narrative review with a special reference to India and other developing countries. Diabetes \& Metabolic Syndrome: Clinical Research \& Reviews. 2020.

21. Borra NK, Kuna Y. Evolution of toxic properties of anti alzheimer's drugs through Lipinski's rule of five. Int J Pure App Biosci. 2013;1(4):28-36.

22. Daina A, Michielin O, Zoete V. SwissADME: a free web tool to evaluate pharmacokinetics, drug-likeness and medicinal chemistry friendliness of small molecules. Scientific reports. 2017;7:42717.

23. Banerjee P, Eckert AO, Schrey AK, Preissner R. ProTox-II: a webserver for the prediction of toxicity of chemicals. Nucleic acids research. 2018;46(W1):W257-W63.

24. Binkowski TA, Naghibzadeh S, Liang J. CASTp: computed atlas of surface topography of proteins. Nucleic acids research. 2003;31(13):3352-5.

25. Gupta MK, Vemula S, Donde R, Gouda G, Behera L, Vadde R. In-silico approaches to detect inhibitors of the human severe acute respiratory syndrome coronavirus envelope protein ion channel. Journal of Biomolecular Structure and Dynamics. 2020(just-accepted):1-17.

26. Morris GM, Huey R, Lindstrom W, Sanner MF, Belew RK, Goodsell DS et al. AutoDock4 and AutoDockTools4: Automated docking with selective receptor flexibility. Journal of computational chemistry. 2009;30(16):2785-91.

27. DeLano WL. The PyMOL molecular graphics system. http://www pymol org. 2002.

28. Chandel V, Raj S, Rathi B, Kumar D. In Silico Identification of Potent COVID-19 Main Protease Inhibitors from FDA Approved Antiviral Compounds and Active Phytochemicals through Molecular Docking: A Drug Repurposing Approach. 2020.

29. Kadioglu O, Saeed M, Johannes Greten H, Efferth T. Identification of novel compounds against three targets of SARS CoV-2 coronavirus by combined virtual screening and supervised machine learning.

30. Masters PS. Coronavirus genomic RNA packaging. Virology. 2019.

31. Báez-Santos YM, John SES, Mesecar AD. The SARS-coronavirus papain-like protease: structure, function and inhibition by designed antiviral compounds. Antiviral research. 2015;115:21-38.

32. Gordon CJ, Tchesnokov EP, Feng JY, Porter DP, Götte M. The antiviral compound remdesivir potently inhibits RNAdependent RNA polymerase from Middle East respiratory syndrome coronavirus. Journal of Biological Chemistry. 2020;295(15):4773-9.

33. Rane JS, Chatterjee A, Kumar A, Ray S. Targeting SARS-CoV-2 Spike Protein of COVID-19 with Naturally Occurring Phytochemicals: An in Silco Study for Drug Development. 2020.

\section{Figures}

A. Spike ectodomain protein

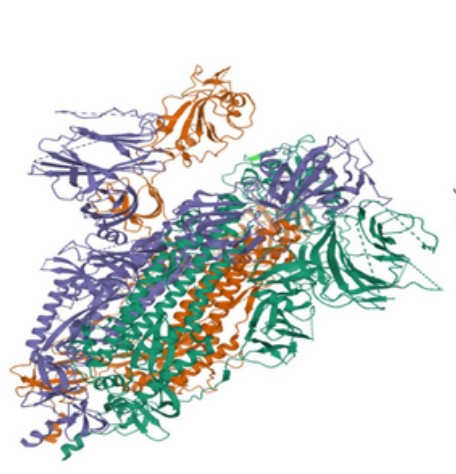

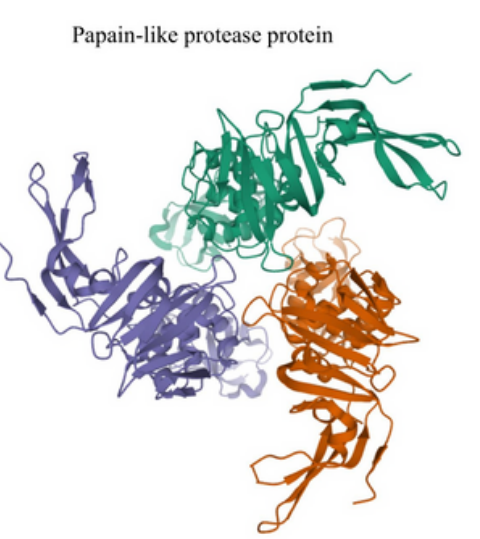

B.

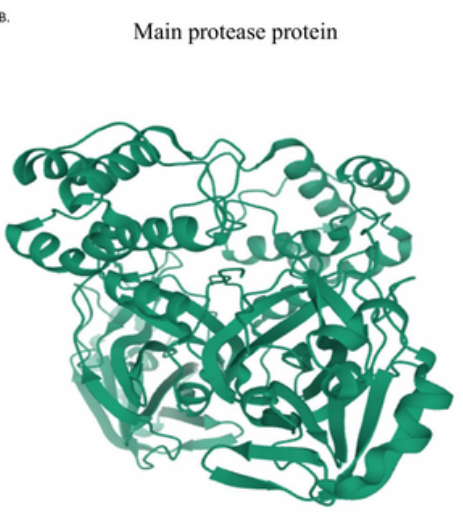

RNA-dependent RNA polymerase

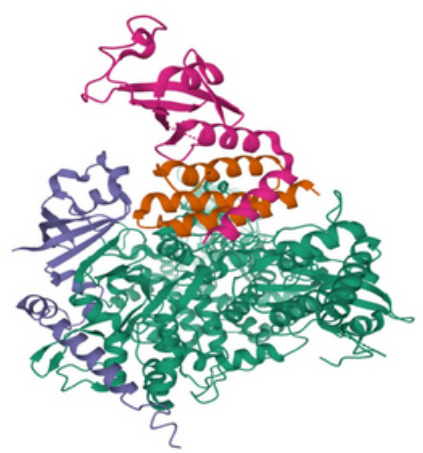


Figure 1

(a): Crystal structure of SARS-CoV2 spike ectodomain protein (open state) (PDB ID: 6VYB) and papain-like protease protein (PDB ID: 6W9C)(b): Crystal structure of SARS-CoV2 main protease protein (PDB ID: 6YB7) and RNA-dependent RNA polymerase (PDB ID: 7BTF)

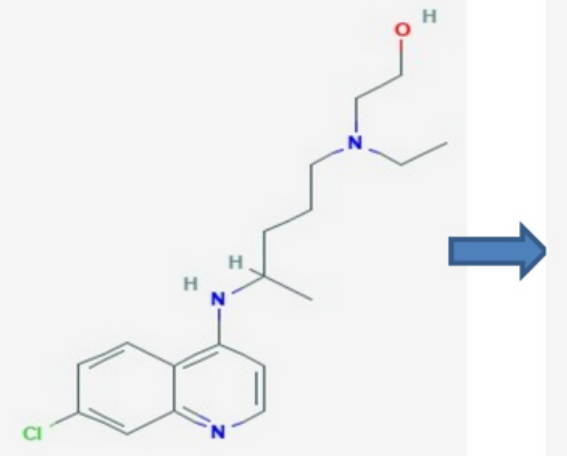

Hydrochloroquine

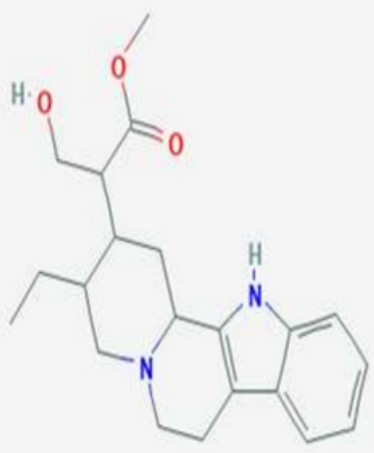

AC1NSULH ((16R)-Dihydrositsirikine)

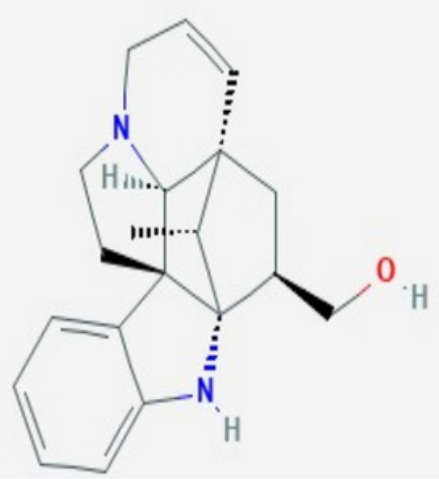

Vindolininol

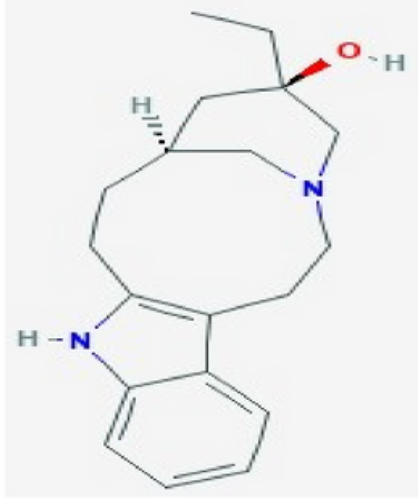

(?)-Velbanamine

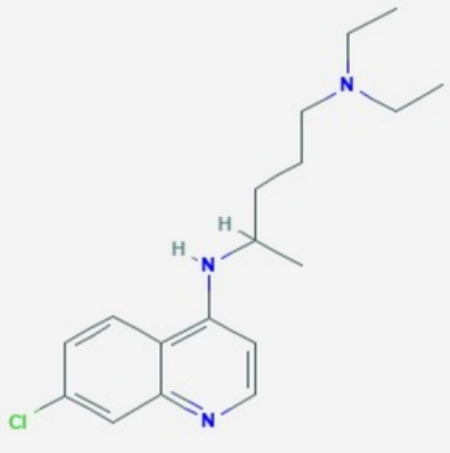

Chloroquine

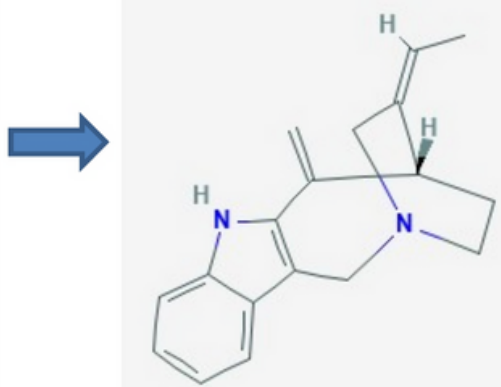

(-)-Apparicine

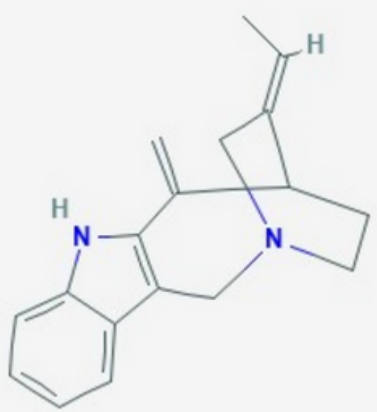

Apparicine

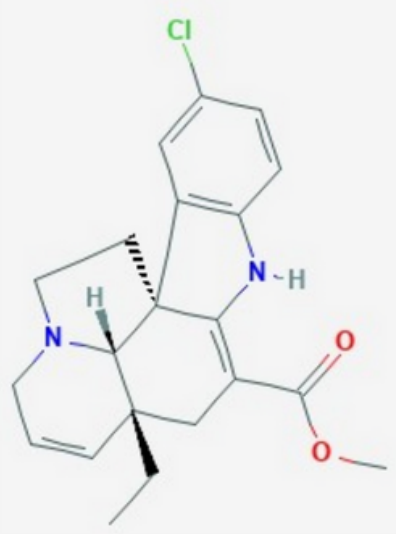

12-Chlorotabersonine

\section{Figure 2}

2D structures of Hydrochloroquine and chloroquine with its analog as phytochemicals from Medicinal Plants IMPPAT database
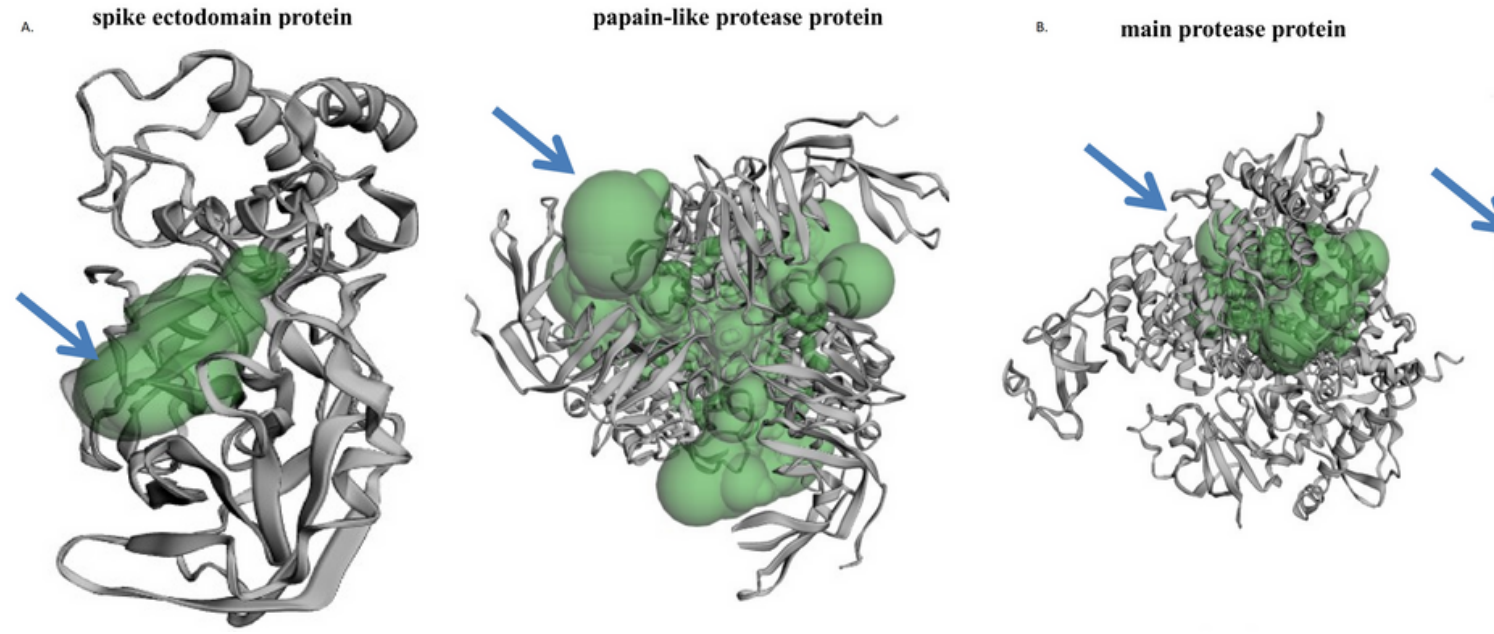

RNA-dependent RNA polymerase

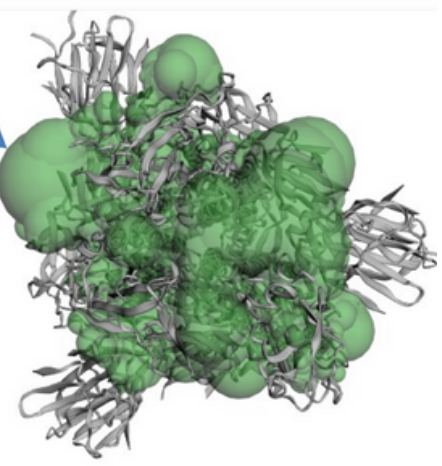


Figure 3

(a): Active site of spike and papain-like protease protein of SARS-CoV2 using CASTp server (b): Active site of main protease protein and RNA-dependent RNA polymerase of SARS-CoV2 using CASTp server
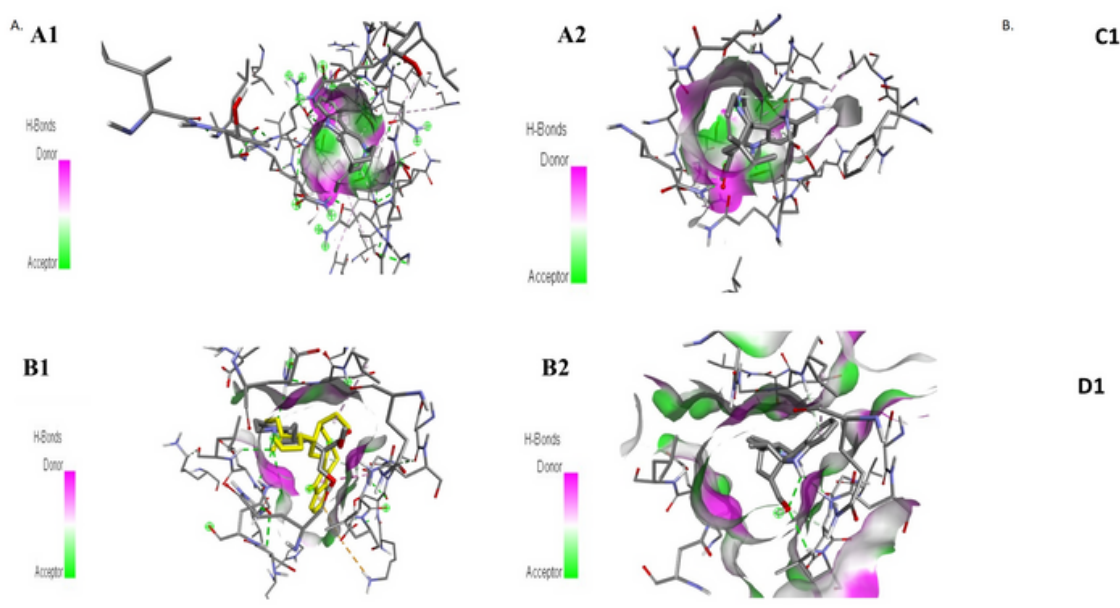

C1

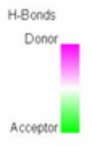

D1

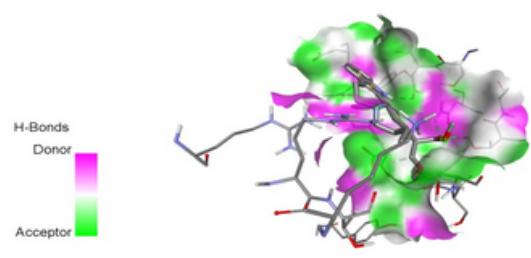

Figure 4

(a): Three-dimensional representation of intermolecular interaction between SARS-CoV2 proteins and pytochemicals A) spike ectodomain protein with 1) Apparicine 2) 12-Chlorotabersonine , B)papain-like protease protein with 1) AC1NSULH 2) Vindolininol, (b): Three-dimensional representation of intermolecular interaction between SARS-CoV2 proteins and pytochemicals C) main protease protein with 1) Vindolininol and D) RNA-dependent RNA polymerase 1) AC1NSULH

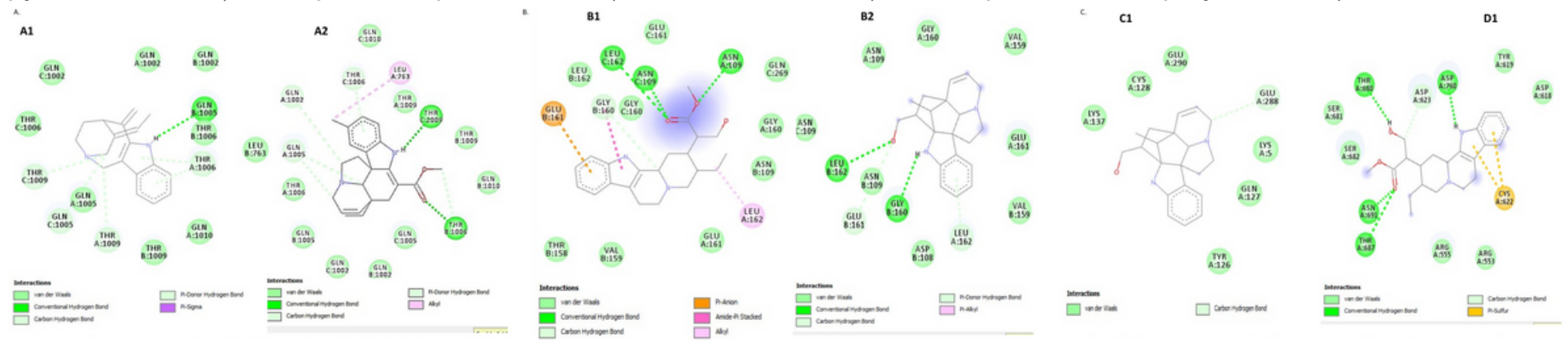

Figure 5

(a):'Two-dimensional' representation of SARS-CoV2 proteins residues forming hydrogen bonds (labelled bold) during interaction with atoms of pytochemicals A) spike ectodomain protein with 1) Apparicine 2) 12-Chlorotabersonine (b):'Two-dimensional' representation of SARS-CoV2 proteins residues forming hydrogen bonds (labelled bold) during interaction with atoms of pytochemicals B)papain-like protease protein with 1) AC1NSULH 2) Vindolininol (c):'Twodimensional' representation of SARS-CoV2 proteins residues forming hydrogen bonds (labelled bold) during interaction with atoms of pytochemicals $C$ ) main protease protein with 1) Vindolininol and D) RNA-dependent RNA polymerase 1) AC1NSULH

\section{Supplementary Files}

This is a list of supplementary files associated with this preprint. Click to download.

- Graphicalabstract.jpg 
- Fig.1aconverted.pdf

Page 16/16 